Jonathan Fox/Nukhet A. Sandal

\title{
Toward Integrating Religion into International Relations Theory
}

This study discusses the multiple potential influences of religion on international relations. These include religious legitimacy, religious worldviews, non-state religious actors including religious institutions, local religious issues crossing borders, transnational religious movements, religious terror, and international issues which overlap with religion such as human rights, the status of women, proselytizing, family planning and stem-cell research. We then begin the process of integrating an understanding of these issues into a major international relations theory: Classical Realism. We find that Classical Realism has room for religion in its role as an explanatory theory, but is not as accepting of religion in its policy prescription role.

Beginning with the new millennium, it has been popular to lament that International Relations (IR) theory ignored religion for much of the $20^{\text {th }}$ century and to focus much of the discussion on why this occurred (see, for example, Philpott 2002; Petito/Hatzopoulos 2003). A limited number of studies, in addition to this, have taken some steps to integrate religion into IR theory by suggesting ways of mutual understanding between theories of IR and issues of faith (Sandal/James 2010) or discussing what must be integrated into IR theory without performing the integration (Fox/Sandler 2004). Other studies discuss some avenues for looking at religion in an IR-related context but do not integrate religion into major IR theories such as Classical Realism (Hurd 2004; Thomas 2005; Hassner 2009). In this essay, we propose to briefly discuss what aspects of religion that any major IR theory must take into account and begin a systematical discussion on how they can be integrated into one such theory: Classical Realism.

\section{The Multiple Influences of Religion}

Religion is a complex multifaceted phenomenon that has multiple and crosscutting influences on international relations. Accordingly, in this section we seek to briefly catalogue the many potential interrelated and overlapping avenues through which religion can potentially shape IR.

\subsection{Legitimacy}

Legitimacy can be defined as »the normative belief by an actor that a rule or institution ought to be obeyed « (Hurd 1999: 381) and can be a powerful tool in IR. Few would 
dispute that religion is a potential source of legitimacy in the domestic context (see, for example, Geertz 1977: 267-268; Juergensmeyer 2008: 10-33) and it can easily be applied to understand the international context. In particular, it can be a powerful tool of persuasion used by policy-makers to convince others, including their own constituents, policy-makers in other countries, and the constituents of those policy-makers. To convince another that your policy preference is legitimate is an important step in convincing them they should support this policy. It is perhaps for this reason that most American presidents have relied on religious imagery to prepare the nation for war. For instance, George W. Bush repeatedly used religious imagery in his justification for the war in Iraq and the war on terrorism (Kengor 2004).

However, as a tool of persuasion religion has at least three limitations. First, this persuasion is often limited by cultural and religious boundaries. For example, invoking Jesus is more likely to sway Christians than Muslims or Jews, much less Hindus or Buddhists. While there are religious themes and concepts that can cross religious borders, they are nevertheless less potent bases for persuasion than a dialogue within a religious tradition. Second, religious persuasion is limited by the religious beliefs of the intended audience. Simply put, those who are more religious are more likely than those who are less religious to be persuaded by religious arguments. Finally, religious persuasion is to a great extent dependent on the credentials of the one using it. That is, in order to most effectively invoke religious legitimacy, one must be seen as actually believing in and observing the tenets of the religious theological framework in question.

\subsection{Worldviews}

Treating religious legitimacy as an instrument of persuasion depicts religion as a tool used cynically by policymakers to advance their goals. This certainly occurs, but religion can also act as an independent motivating force. The argument that religious beliefs influence people's worldviews and identities and that religious motivations influence behavior is not in dispute and is well grounded in the social sciences literature (see for example, Seul 1999: 558-562; Fox 2002: 106-110; Juergensmeyer 2008: 19-22). Even classically anti-religious thinkers such as Karl Marx acknowledge its power, in this example as a »false consciousness « and the »opiate of the masses « but nevertheless a potentially potent influence on behavior.

This can influence international relations in two ways. First, religion can influence the belief system or worldview of a policy maker. To the extent that this is true, religion has the potential to influence that policy maker's decisions. In cases of religious belief, this can lead to extreme and intractable policies because »religion deals with the constitution of being as such. Hence, one cannot be pragmatic on concerns challenging this being (Laustsen/Wæver 2000: 719). Ron E. Hassner (2009: 38-50) similarly argues that religious conflicts are intractable because they are $»$ indivisible $\ll$. This means that the object of a conflict cannot be replaced or divided without signi- 
ficantly diminishing its value. In these cases there is no solution that can satisfy both sides.

A policy maker's worldview does not need to be completely religious for religion to have an influence. Most individuals have complex worldviews influenced by multiple factors. As long as religion is one among the many influences on one's worldview, it can still influence decisions. Even ideologically secular worldviews are similarly influenced by religion in that they involve the negation of religion. Only those who are wholly apathetic to the issue of religion can be said to have worldviews that are religion-free. In fact, it is likely that the most significant influence of religious beliefs on the decisions of policymakers is not in the more blatant examples like Iran and $\mathrm{Al}$ Qaeda, but rather in the cumulative influence of the religious elements which are to varying degrees part of many policy makers' worldviews.

That being said, the number of states which embrace religion as their national ideology or at least an element of their national ideology is larger than many would expect. Jonathan Fox (2008) in a study of 175 states between 1990 and 2002 demonstrates that nearly half of them support a single religion. 46 states $(26.2 \%)$ have official religions and an additional $36(20.6 \%)$ while not declaring an official religion support one religion more than others. Of course, official religions mean different things to different states. For example, while the UK and Saudi Arabia both have official religions, few would claim that the impact of religion on domestic policy in these two states is the same. Yet based on an analysis of the Religion and State dataset used in Fox's (2008) study, the 82 states which officially or unofficially support a single religious ideology legislate about two-and-a-half times as much religious legislation as do other states. This influence of religious ideologies in the domestic arena implies a potential influence in the international arena. In extreme cases foreign policy agendas can include exporting a state's religious ideology.

Second, widely held religious beliefs among a policy maker's constituents can place constraints on policy options. It can be unwise even for policymakers in autocratic regimes to take an action that runs directly counter to some belief, moral, or value that is widely held by their constituents. To do so could easily undermine the legitimacy of a regime and its rulers. For example, in the Arab-Israeli conflict, both sides need to weigh how their populations will react to any agreement. This is particularly true of agreements dealing with the disposition of holy sites like the city of Jerusalem, which are widely considered indivisible issues.

\subsection{Institutions and Other Non-State Religious Actors}

There is a growing literature arguing that religious institutions can play a significant role in domestic politics. For one, any existing institution, including religious institutions, can be used as potent agents of political mobilization. This mobilization strategy is particularly effective because religious institutions generally have most of the organizational resources necessary for political mobilization. This includes meeting places in which people regularly congregate, communication networks, members with 
organizational and leadership skills, economic assets, and good access to the media. In some cases they are part of international networks (Johnston/Figa 1988; Wald et. al. 2005: 131-136). For instance, organizing a pro-Israel demonstration in the US is far easier if accomplished by contacting as many Synagogues as possible and asking them to help mobilize their congregants than building the organizational structure to mobilize demonstrators from scratch. This is exactly what happened to mobilize over 100,000 people for a pro-Israel demonstration in Washington DC in April 2002.

Religious institutions are also not unrelated to religious worldviews. One of the purposes of religious institutions is to safeguard and propagate the religious worldview and belief system upon which the institution was founded. Political activities intended to accomplish this are not uncommon. Also, as important arbiters of religious legitimacy, religious institutions have the potential to influence the use of legitimacy in support or opposition of foreign policies.

While this literature focuses on the pursuit of goals in the domestic arena, it is clear that religious organizations often pursue political objectives in the international arena. For example, the World Council of Churches played a key role in supporting the various international divestment and actions which led to the fall of the Apartheid regime in South Africa (Warr 1999). Also, religious non-governmental organizations are active throughout the world engaging in humanitarian and missionary work as well as supporting political causes (Thomas 2005: 98-115).

\subsection{Local Religious Issues and Phenomena Cross-Borders}

While most treatments of the concept of interdependence focus on economic interdependence, the general concept that what happens locally can have an international impact is more broadly applicable in general and applicable to religion specifically. Perhaps, this is most obvious with regard to religious conflicts. While there are few international wars which are overtly religious, local conflicts with religious overtones are common. ${ }^{1}$ These conflicts can influence the international arena in a number of ways including the prevalence of humanitarian intervention and the flow of refugees across borders. In addition, the conflicting parties can seek to internationalize a conflict through the use of international forums. For example, Arab and Islamic states often use the UN and UN-sponsored conferences as forums to demonize Israel. The UN-sponsored World Conference Against Racism, Radical Discrimination, Xenophobia, and Related Intolerance held in Durban, South Africa in 2001 is one example of such an endeavor (Fox/Sandler 2004: 77-79).

Israel also provides a good example of a more recent form of internationalization of conflict. There is an increasing belief in some elements of the world community that some crimes transcend borders and international courts such as the International Court of Justice must punish the worst war criminals and offenders of human rights norms. A number of European countries have passed laws that allow their courts to

1 For an enumeration of local religious conflicts see Fox (2004: 239-267). 
hear such cases, claiming a form of universal jurisdiction over these types of crimes. These courts also provide potential forums for the sides of religious conflicts. Palestinian organizations have been active in pursuing prosecutions of Israeli soldiers and officials in these forums, claiming that they are responsible for crimes which fall under this universal jurisdiction.

Of course, all of these avenues for the spread of conflict across borders also apply to non-religious conflicts. However this does not take away from the fact that it happens with local religious conflicts and that because of this, these conflicts influence IR. Also, since the late 1970s, religious conflicts have been becoming a greater proportion of all conflict and, by one accounting, as of 2002, became a majority of all domestic violent conflict (Fox 2007: 405).

\subsection{Transnational Religious Movements}

In practice, the dividing line between local religious issues and phenomena crossing borders and transnational ${ }^{2}$ religious issues and phenomena is blurred. Transnational religious movements include any religious ideology or phenomenon that operates in multiple states and pursues an agenda on a transnational level. From this perspective violent movements seeking to impose their religious ideology on others such as $\mathrm{Al}$ Qaeda are similar to international religious hierarchies such as the Catholic Church or pacifist religious movements such as that headed by the Dalai Lama. All of these movements seek to significantly shape political agendas and do not confine themselves to a geographical location, though clearly their specific agendas and tactics differ significantly.

Religious fundamentalism is, perhaps, the most prominent transnational religious phenomenon. Fundamentalists seek to protect their religious identities and traditions from modernity and secularism by, among other things, creating a society which strictly follows their religious ideals. Some, though not all, fundamentalists seek to also impose their ideology and preferred sociopolitical structure on others. Ultimately many fundamentalist movements hope to create a world-wide religious society that knows no borders. Thus, their goal is clearly a transnational one (Appleby 2000: 87-94). This is facilitated by the fact that most fundamentalist and non-fundamentalist religious movements consider their beliefs to be universal truths which do not recognize international borders.

The international aspect of this agenda is accomplished through a number of strategies. First, many movements seek to influence or take control of state and local governments. This has international implications because when they manage to gain control of a state, their agenda does not stop at enforcing their religious ideals locally. They also use the state to spread the revolution worldwide. Afghanistan under the

2 It is important to note that in this context the term »transnational« does not refer in particular to the transnationalism school of thought that emerged in IR theory during the 1970s. See Keohane/Nye (1977). 
Taliban regime and post-revolutionary regime in Iran are prime examples of this. Second, fundamentalists try to take over religious institutions and become the sole arbiters of religious legitimacy and authority. When successful, they can use this monopoly of religious legitimacy and authority to portray their goals as correct and moral and to paint any who oppose them as evil and subversive. Third, these movements form transnational linkages with other like-minded movements worldwide. Fourth, they make use of the media and international communications to both coordinate activities and spread their message worldwide.

Religious fundamentalism has been linked to religious terrorism. Religion has been a justification for terrorism for millennia (Rapoport 1984: 659), and it is becoming the most common motivation for terrorism in the world today (Weinberg/Eubank 1998; Rapoport 2002). Despite recent prominence of Islam in religious terrorism, it is important to emphasize that both currently and historically religious terrorism has been perpetrated by the extremists of almost every religion. While this manifestation of religion is sensational, it can primarily be seen as one tactic among many used by transnational religious movements. It is a convenient tactic because these movements often do not command enough influence to achieve their goals peacefully and do not have the military power to engage in conventional wars against powerful, and even not so powerful, states.

Be that as it may, it is clear that religious terror is becoming a significant factor in IR. It has contributed to the formation or realignment of international alliances between states in order to fight it. It has facilitated recognition that non-state actors can be a potent force which undermines the traditional state monopoly on the use of violence. It has also influenced the foreign policies of many states and will likely continue to do so for the foreseeable future.

There are a number of additional transnational trends, issues and phenomena which overlap with religion that are worthy of note, though space does not allow their detailed discussion here. First, the issue of religious and human rights, including religious rights, is becoming an increasingly international issue. It is becoming an important element of the foreign policies of many Western states and has been included in a number of international documents and treaties. Second, the issue of women's rights is becoming an increasing source of tension between the West and non-West. Many non-Western states place significant restrictions on women that are incongruent with Western ideas of equality for women. Religion is often used to justify many of these restrictions. Third, proselytizing constitutes a significant potential source of international tension. Numerous religious groups, most prominently Muslim and Christian groups, send missionaries to states across the world. In 2002, 77 states, including several in Western Europe, placed some form of restrictions on proselytizing. Many of these restrictions were specifically aimed at foreign missionaries (Fox 2008: 359). Finally, biological-scientific issues such as family planning and stem-cell research have resulted in tensions, primarily across the secular-religious divide rather than across different religious identities. 


\section{Toward Integrating Religion into Classical Realism}

It is important to realize that enumerating which religious factors can potentially influence IR is only a first step toward understanding the role of religion in International Relations. Religion is clearly not the only factor which influences international politics. Thus, this understanding of religion's role must be combined with our existing knowledge of the workings of the discipline. This can potentially be accomplished by either integrating religion into existing IR theories or by constructing new theories which can account for religion as well as other factors. It is our belief that discarding decades, and in some cases centuries, of work by IR scholars should be a last resort, and, accordingly, the best route is to find ways to integrate an understanding of religion into existing theories of international politics. We further believe that this is possible and, in this section, discuss briefly how religion can be integrated into a single IR theory: Classical Realism. While this discussion does not achieve a fully integrated theory, it does demonstrate the possibility of combining an understanding of religion with the insights of classical realism and the likely avenues toward full integration.

While we acknowledge that Classical Realism is not a monolithic school of thought, space limitations require that our discussion treat it in a more general context. Classical Realism focuses on states as actors in an anarchic international system with no overarching authority. In this context, states seek power in a competitive environment and are rational in the sense that they have consistent, ordered preferences and they pick the utility-maximizing choice. Although Realism allows for a number of independent variables ranging from »human nature « to »distribution of capabilities «, many scholars who have written on IR theory have expressed their pessimism about the integration of culture and identity in general, and this pessimism certainly extends to the integration of religion (Schweller 1988: 20; Lapid 1996; Zakaria 1999: 32-35; Hobden 2001: 42-59).

Unlike some other theories of IR, Classical Realism has deep historical roots in that Thucydides (400 B.C.E), Niccolò Machiavelli and Thomas Hobbes are considered among the »fathers « of the Realist paradigm. Each of these thinkers recognized on a practical level that religion is an engine of power in the society that can be significant in legitimating governments and their actions (Machiavelli 1984 [1513]: 144; Hobbes 1985 [1651]:168; Jordan 1986). Thus, the roots of Classical Realism do not exclude religion.

If one examines the writings of central $20^{\text {th }}$ century realist thinkers, the acknowledgement of religion's power remains within their paradigm. For example, Hans J. Morgenthau argues that

»carrying their idols before them, the nationalistic masses of our time meet in the international arena, each group convinced that it executes the mandate of history,... and that it fulfills, a sacred mission ordained by providence, however defined. Little do they know that they meet under an empty sky from which the gods have departed « (Morgenthau 1956: 234).

Others address the issue more indirectly alluding to human nature which can be irrational. For instance, Reinhold Niebuhr (1932: xx) asserted that »the easy subser- 
vience of reasons to prejudice and passion, and the consequent persistence of irrational egoism, particularly in group behavior, make social conflict an inevitability in human history, probably to its very end«. Similarly, George F. Kennan (1967: 319), the American diplomat who introduced the concept of »containment «, lamented that »I wish I could believe that the human impulses which give rise to the nightmares of totalitarianism were ones which Providence had allocated only to other peoples and to which the American people had graciously been left immune«.

The importance of this trend among classical realists is a general acknowledgement that while religious motivations make for bad foreign policy and, therefore, »ought not « influence decision making, in practice this influence does exist. This means that integrating religious worldviews into Classical Realism is to accept that religion, along with other non-material factors, can still be assigned value by decision makers and, accordingly be included in cost-benefit calculations. This does not preclude the pursuit of an agenda, even one influenced by »non-rational« factors such as religion, through traditional classical realist means.

Our central argument with regard to religious legitimacy is that religious legitimacy, like any form of legitimacy, is a potent tool of persuasion which can be applied to foreign policy goals. We argue that this concept is compatible with Classical Realism, and in fact, can be considered a form of power or influence. Although Classical Realism emphasizes material power and interest, these concepts are used flexibly enough to permit integration of less tangible forms of power such as legitimacy and persuasion. For example, Morgenthau argues that power's

»content and the manner of its use are determined by the political and cultural environment. Power may comprise anything that establishes and maintains the control of man over man. Thus, power covers all social relationships which serve that end, from physical violence to the most subtle psychological ties by which one mind controls another « (Morgenthau 1956: 8-9).

Niebuhr (1996: 260) also argues that man can »create an endless variety of types and combinations of power, from that of pure reason to that of pure physical force $\ll$. Thus, if religious legitimacy is a tool that can persuade others to do as you wish, it can be considered a form of power that is compatible with the classical realist framework.

As Classical Realism focuses on states as actors, the integration of an understanding of religious institutions, transnational religious movements and other non-state religious actors is likely best left to other IR theoretical traditions such as Neoliberalism or the Solidarist branch of the English School which do not take the state as their central referent point. Nevertheless, it is not impossible to find several avenues for integrating these factors into Classical Realism.

First, if one accepts that Classical Realism allows for foreign policy decisions to be influenced by »non-rational« factors such as religion, it is not difficult to argue that the religious institutions, which to a great extent control and propagate religious ideology can have an influence on both the content and application of religious ideologies which in this manner influence beliefs and policy preferences of policy makers. Similarly, if one accepts that religious legitimacy is a source of power through persua- 
sion, it is simple to accept that religious institutions and other religious actors can influence what a religion can and cannot legitimate. The next logical step in this line of reasoning would be that religious institutions and actors could pursue an agenda of influencing decision makers to follow a particular policy and independently use religious legitimacy to support or oppose specific policies. Thus, the primary actors in this framework remain states, but it allows for the behavior of these states to be influenced by religious institutions and actors.

Second, the Classical Realist concept of the security dilemma can be linked to religion. Men, groups or leaders are »concerned about their security from being attacked, subjected and annihilated by other groups or individuals « and their attempts to gain more power for their security »renders the others more insecure and compels them to prepare for the worst« (Herz 1950: 157). This concept can be applied to religious groupings as well as states.

Third, non-state religious actors can influence the power balance by creating an alternative to the existing state identity. Religious minorities, by rebellion or by resisting the prevalent doctrines (religious or secular) in the public sphere, might threaten the organization of a state, and there is a strong likelihood that the religion component will be used to justify this stance (Lincoln 1985: 276-279). Religious institutions can oppose the policies of the state and withdraw their support (if there was any) in the event of state policies not coinciding with the interests of the religious elite (Fox 1999: 134). Similarly, transnational movements, such as Al Qaeda, can create alliances among like-minded individuals which seek to take over existing states or carve out new states which function based on religious ideologies.

Fourth, transnational religious movements, as well as religious identity in general, can be seen as a basis for alliances between states. Just as political ideologies were the basis for alliances during the Cold War, religious ideologies and identity serve as the basis for alliances. Huntington $(1993 ; 1996)$ essentially made this argument but perhaps overreached in stating that these religious groupings would be the primary basis for world alliances and conflict, rather than one influence among many.

All of these avenues for a classical realist understanding of non-state religious actors are linked to the state, as are the avenues for understanding religious worldviews and legitimacy. This arguably results in an incomplete integration of this aspect of religion into classical realist theory which does not fully account for the full spectrum of the influence of non-state religious actors on IR. However, this inability of Classical Realism to fully account for non-state actors and the impact of domestic politics on foreign policy is a generally acknowledged limitation of Classical Realism. Despite this limitation, Classical Realism has been a potent tool for understanding IR. Each of the major theories of IR has similar limitations in that they focus on explaining some aspects of IR at the expense of other aspects.

Within this context, we have demonstrated that most of the potential influences of religion on IR can be integrated into classical realist thought. Though, to be clear our argument is that Classical Realism has room to accept that such influences exist but would classify any policy based on these influences as a poorly designed foreign policy. Thus, Classical Realism has room for religion in its role as an explanatory 
theory, but is not as accepting of religion in its policy prescription role. Nevertheless, this is significant because it bodes well for the prospects of allowing religion to influence our understanding of IR without discarding the insights that have proven successful in the past to understand other influences. It also bodes well for the potential to integrate an understanding of religion into other major IR theoretical traditions.

\section{References}

Appleby, R. Scott 2000: The Ambivalence of the Sacred: Religion, Violence, and Reconciliation, New York, NY.

Fox, Jonathan 1999: Do Religious Institutions Support Violence or the Status Quo?, in: Studies in Conflict and Terrorism 22: 2, 119-139.

Fox, Jonathan 2002: Ethnoreligious Conflict in the Late 20th Century: A General Theory, Lanham, MD.

Fox, Jonathan 2004: Religion, Civilization and Civil War: 1945 Through the New Millennium, Lanham, MD.

Fox, Jonathan 2007: The Increasing Role of Religion in State Failure: 1960-2004, in: Terrorism and Political Violence 19: 3, 395-414.

Fox, Jonathan 2008: A World Survey of Religion and the State, New York, NY.

Fox, Jonathan/Sandler, Shmuel 2004: Bringing Religion into International Relations, New York, NY.

Geertz, Clifford 1977: Centers, Kings and Charisma: Reflections on the Symbolics of Power, in: Ben-David, Joseph/Clark, T. Nichols (eds.): Culture and its Creators, Chicago, IL, 150-171.

Hassner, Ron E. 2009: War on Sacred Grounds, London.

Herz, John H. 1950: Idealist Internationalism and the Security Dilemma, in: World Politics 2: 2, 157-180.

Hobbes, Thomas [1651] 1985: The Leviathan, New York, NY.

Hobden, Steven 2001: Historical Sociology: Back to the Future in International Relations, Cambridge.

Huntington, Samuel P. 1993: The Clash of Civilizations?, in: Foreign Affairs 72: 3, 22-49.

Huntington, Samuel P. 1996: The Clash of Civilizations and the Remaking of the World Order, New York, NY.

Hurd, Elizabeth S. 2004: The Political Authority of Secularism in International Relations, in: European Journal of International Relations 10: 2, 235-262.

Hurd, Ian 1999: Legitimacy and Authority in International Politics, in: International Organization 53: 2, 379-408.

Johnston, Hank/Figa, Jozef 1988: The Church and Political Opposition: Comparative Perspectives on Mobilization Against Authoritarian Regimes, in: Journal for the Scientific Study of Religion 27: 1, 32-47.

Jordan, Borimir 1986: Religion in Thucydides, in: Transactions of the American Philological Association 116, 119-147.

Juergensmeyer, Mark 2008: Global Rebellion: Religious Challenges to the Secular State: From Christian Militias to Al Qaeda, Berkeley, CA.

Kengor, Paul 2004: God and George Bush: A Spiritual Life, New York, NY.

Kennan, George F. 1967: Memoirs 1925-1950, Boston, MA.

Keohane, Robert/Nye, Joseph 1977: Power and Interdependence, Boston, MA.

Lapid, Yosef 1996: Culture's Ship: Returns and Departures in International Relations Theory, in: Lapid, Yosef/Kratochwil, Friedrich (eds.): The Return of Culture and Identity in International Relations Theory, Boulder, CO, 3-20. 
Laustsen, Carsten B./Woever, Ole 2000: In Defense of Religion: Sacred Referent Objects for Securitization, in: Millennium, 29: 3, 705-739.

Lincoln, Bruce (ed.) 1985: Religion, Rebellion and Revolution, London.

Machiavelli, Niccolò [1513] 1984: The Discourses, New York, NY.

Morgenthau, Hans J. 1956: Politics Among Nations, New York, NY.

Niebuhr, Reinhold 1932: Moral Man and Immoral Society: A Study of Ethics and Politics, New York, NY.

Niebuhr, Reinhold 1954: Christian Realism and Political Problems, London.

Niebuhr, Reinhold 1996: Nature and Destiny of Man II, Westminster.

Petito, Fabio/Hatzopoulos, Pavlos 2003: Religion in International Relations: The Return from Exile, New York, NY.

Philpott, Daniel 2002: The Challenge of September 11 to Secularism in International Relations, in: World Politics 55: 1, 66-95.

Rapoport, David C. 1984: Fear and Trembling: Terrorism in Three Religious Traditions, in: American Political Science Review 78: 3, 658-677.

Rapoport, David C. 2002: The Four Waves of Rebel Terror and September 11, in: Anthropoetics 8: 1 (Online-Publikation).

Sandal, Nukhet A./James, Patrick 2010: Religion and International Relations Theory: Towards a Mutual Understanding, in: European Journal of International Relations, forthcoming.

Schweller, Randall 1988: Deadly Imbalances: Tripolarity and Hitler's Strategy of World Conquest, New York, NY.

Seul, Jefferey R. 1999: »Ours is the Way of God «. Religion, Identity and Intergroup Conflict, in: Journal of Peace Research 36: 3, 553-569.

Thomas, Scott M. 2005: The Global Resurgence of Religion and the Transformation of International Relations: The Struggle for the Soul of the Twenty-First Century, New York, NY.

Wald, Kenneth D./Silverman, Adam L./Friday, Kevin S. 2005: Making Sense of Religion in Political Life, in: Annual Review of Political Science 8, 121-143.

Thucydides [400 B.C.] 1972: The Peloponnesian War, Baltimore, MD.

Warr, Kevin 1999: The Normative Promise of Religious Organizations in Global Civil Society, in: Journal of Church and State 41: 3, 499-523.

Weinberg, Leonard B./Eubank, William L. 1998: Terrorism and Democracy: What Recent Events Disclose, in: Terrorism and Political Violence 10: 1, 108-118.

Zakaria, Fareed 1999: From Wealth to Power: The Unusual Origins of America's World Role. Princeton, NJ. 